University of Michigan Law School

University of Michigan Law School Scholarship Repository

Articles

Faculty Scholarship

1918

\title{
Liability of Corporations for Slander
}

Horace LaFayette Wilgus
University of Michigan Law School

Available at: https://repository.law.umich.edu/articles/904

Follow this and additional works at: https://repository.law.umich.edu/articles

Part of the Business Organizations Law Commons, Communications Law Commons, and the Comparative and Foreign Law Commons

\section{Recommended Citation}

Wilgus, Horace LaFayette. "Liability of Corporations for Slander." Mich. L. Rev. 17 (1918): 170-2.

This Response or Comment is brought to you for free and open access by the Faculty Scholarship at University of Michigan Law School Scholarship Repository. It has been accepted for inclusion in Articles by an authorized administrator of University of Michigan Law School Scholarship Repository. For more information, please contact mlaw.repository@umich.edu. 
LIABIIITY of CoRporations For SLANDER.-S. entrusted by the president and general manager of a corporation with the business of obtaining a settlement from plaintiff for a mistakenly supposed shortage in his ac:ounts with the corporation, falsely orally charged him with embezzlement. This charge was made to $R$., president of another corporation for which the plaintiff' was working at the time, and as a step toward getting a settlement by the plaintiff. On the request for a directed verdict, by the defendant, the legal question was presented whether a corporation is liable for slander spoken by the agent of the corporation in the course of his business and in the scope of his authority. and without direction to use, or ratification of the use of, the words spoken, by the directors or chief officers of the corporation. Held: the corporation is so liable. Buckcye Cotton Oil Co. v. Sloan, (I9I8, U. S. Dist. Ct. Tenn.), 250 Fed. 7r2. The court says: "We perceive no sound reason why the liability of a corporation for the act of its agent should differ in an action for slander from that in actions for libel, or other torts, and cannot agree with the view expressed in Southern Ice Co. v. Black, (I916), 136 Tenn. 391, I89 S. W. 861, Ann. Cas. I9I7 E. 695 .

It is only within recent years that a corporation's liability for slander, as for other torts, has become settled in the United States. Townshswd, LIBEL AND SLANDER (3d. Ed. 1877 ), \$265, said there could be no agency in slander: and since a corporation can act only through agents, it would follow that it could not be guilty of slander.

ODGERS, LIBEI AND StaNDER, (Ist. Ëd. I88I) said: "A corporation will not, it is submitted be liable for any slander .uttered by an officer even though he be acting honestly for the benefit of the corporation and within the scope of his duties, unless it can be proved that the corporation expressiy ordered and directed that officer to say those very words: for slander is the voluntary and tortious act of the speaker. NEWELL, DEFAMATION, (Ist Ed. I890), p. 36I says substantially the same. No cases are cited by any of these authors. but in I897, the Queens -Bench Division of the High Court of Ontario, in Marshall v. Railroad Co., 28 Ont. 24I, by ARMrour, C. J., says as to one of the counts, "We are all agreed that slander will not lie against a corporation," and would not permit argument on the point. This was a suit 
by a workman. discharxed under a slanderous charge, by the road master who had authority to hire and discharge an employe.

On the other hand in Dodge v. Bradstreet ( 1880 ) 59 How. Pr. (N. Y.) Io4, and in Buffalo Lubricating Oil Co. v. Standard Oil Co. (1836), 42 Hun. (N. Y.) I53, it was held that a corporation could be a party to a conspiracy to slander, and be liable for such slander. Morawitz. Private CorporaTroNs (2d. Ed. 1886), par. 727, said a corporation can "be held responsible for libel or slander published by its authority." He cites sixteen cases,-all libel or malicious prosecution cases. but no slander cases. Corporatiuns were held liable for malicions prosecution in the Uinited States as early as 1853, in Goodspeed v. East Haddam Bank, 22 Conn. 530, 58 Ar. Dec. 439, Wirgus, CoRporation CASES, 1296, but in England not till 1900, in Cornford v. Carlton Bank, $L t d$. I Q. B. 22 C. A. As early as I858. corporations were held liable for libel by the United States Supreme Court in Philedelphia, etc.. R. R. Co. v. Quigley, 2r How. 202; and in the same year by the Finglish Courts in Whitfield v. South Eastern Ry. Co., El. Bl., \& El. II5, 96 E. C. L. 115 .

Odgers, LIBEL \& SLANDER (5th Ed. I9II) leaves out the statement quoted above, and puts nothing in its place as to Slander. NEWELL, DLFA rsaTroN, (3d. Ed. I914). also leaves out the above statement and says a corporation is liable for libel if the publication is made by authority, or ratified, or made by one of the corporation's "agents or servants in the course of the business in which he was employed. And the same is true as to slander." He points out correctly that the late cases are not in accord: some holding that the use of the words must be authorized or ratified, officially, to make the corporation liable, as in Behre v. National Cash Register Co. (I\&97), roo Ga. 213, 62 Am. St. R. 320, 27 S. E. 986. Alabama, (Republic Iron Co. v. Self, 192 Ala. 403, 68 So. 328, L. R. A. I915 F. 516); Kentucky (Pruit v. Goldstein Millinery Co., (I916), I69 Ky. 655, I84 S. W. II34,-a partnership case, but citing several Kentucky corporation cases); Massachusetts, (Kane v. Boston M. L. Ins. Co., (1908), 200 Mass. 265, 86 N. E. 302) ; Michigan, (Flaherty v. Maxwell Motor Co., (1915), I87 Mich. 62, 153 N. W. 45); and Tennessee, (Southem Ice Co. v. Black, supra) follow this doctrine.

The following, however (with much better reason), hold the corporation liable for slander spoken by an agent or servant in the course of his employment, and in the scope of his authority, the same as for other torts: Arkansas, (Waters Pierce Oil Co. v. Bridwell, (191), 103 Ark. 345, 147 S. W. 64, Ann. Cas. 1914 B 837, contrary to what is said in Lindsay v. Railroad Co., (19ro), 95 Ark. 534, 129 S. W. 807 ; Minnesota, (Roemer v. Brequing Co., (1916), 132 Minn. 399, I57 N. W. 640, L. R. A. 1916 E 771) ; Mississippi, Rivers v. Yazoo R. R. Co., (1907), 90 Miss. rgo, 43 So. 47 I, 9 L. R. A. (N. S.) 93I) ; Missouri, (Fensky v. Casualty Co., (I915), 264 Mo. 154, 174 S. W. 416. Ann. Cas. I9I7 D 963); New York. (Kharas v. Barron C. Collier, Inc., (1916), 157 N. Y. S. 410, overruling Eichner v. Bowery Bank, (1897). 24 App. D. 6.3); North Carolina, (Sawyer v. Railroad Co., (1906), 142 N. C. I, 54 S. E. 793, 115 Am. St. R. 716, Ann. Cas. 440); Ohio, (Citizens Gas Co. v. Black, (1917), 95 Oh. St. 42, I15 N. E. 495, L. R. A. 1917 D 
559) : South Carolina, (Hypes v. Southern Ry. Co., (190z), 82 S. C. 315, 64 S. E. 395,26 L. R. A. (N. S.) 873, 17 Ann. Cas. 620); Texas (Southwestern Telegraph Co. v. Long, (1916),-Tex. Cri. App.-, 183 S. W. 421); and Grand Union Tea Co. v. Lord, (1916. E. Dist. Va.), 23I Fed. R. 390.

There seem to be no English cases directly holding a corporation liable for slander, but in Citizens Life Asstrance Co., Ltd., จ. Brozun, (1904), A. C. 423,73 L. J. P. C. N. S. 102, 90 L. T. N. S. 739,20 T. L. R 497, 53 W. R. 176,6 B. R. C. 675 , the Privy Council rules that a corporation is liable for libel, "Although the servant may have had no actual authority, express or implied, to write the libel complained of, if he did so in the course of an employment which is authorized." The leading English authors state the corporation's liability for torts in terms broad enough to include liability for slander by an agent in the course of his employment, and within the scope of his general authority, but cite no cases of slander. See Odgers, LIBEL and SLANDER, 5th Ed., p. 592; Crerk and Lindsell, Torts, Canadian Ed. 1908, pp. 60-63; PolLOCK, ToRrs, 9th Ed. 1912, pp. 6I-63; SAIMOND, Torrs, 4th Ed. 19I6, pp. 60-64; HalsBURY's Laws of ENGLAND, Vol. 5. Companies, igio, p. 309; Hamirion's Company Law, 2d. Ed., rgot, p. I2I, Canadian Ed.. IgIr, pp. 108-9: LINDIEY, CoMrpany LAw, 6th. Ed. 1902, p. 257 et seq.; Palmiser, Company Precedents, Vol. I, 1912, p. 38.

There have been several Scotch cases, and in Finburgh v. Moss' Enipires, Ltd., (1908), S. C. 928 , it was expressly ruled that "an employer (a corporation), is liable for a verbal slander uttered by his servant in the course of the servant's employment and for the benefit of the employer." The court relies upon Barwick v. English Joint Stock Bank, (I867), L. R. $2 \mathrm{Ex}$. 259, (a case of fraud), and Citizen's Life Assurance Co., Ltd., v. Brown. Supra. In Aiken v. Caledonian Ry. Co., (I9I3), S. C. 66, where the cases are reviewed, the judges insist that "for the benefit of the employer," are important on the question of liability. - not necessarily meaning that the employer should reap some benefit from the use of the words. but the facts alleged and proved should show "that the verbal slander complained of is a slander that should be held in law to be imputable to the principals, so as to justify the issue that it was a slander uttered by them, by or through their servant." See also Mandelston v. North British Ry., (1917), S. C. 442 . to same effect.

H. L. W. 